\title{
Gender Diversity and Board Performance: Women's Experiences and Perspectives
}

\section{Nada K. Kakabadse, Catarina Figueira, Katerina Nicolopoulou, Jessica Hong Yang, Andrew P. Kakabadse, and Mustafa Özbilgin}

Correspondence to: Catarina Figueira, Cranfield School of Management, Cranfield University, Cranfield, Bedfordshire MK43 0AL, UK. Phone: +44 (0)1234 754846, Fax: +44 (0)1234 752106, catarina.figueira@cranfield.ac.uk

Despite considerable progress that organizations have made during the past 20 years to increase the representation of women at board level, they still hold few board seats. Drawing on a qualitative study involving 30 companies with women directors in the United Kingdom, the United States, and Ghana, we investigate how the relationship between gender in the boardroom and corporate governance operates. The findings indicate that the presence of a minority of women on the board has an insignificant effect on board performance. Yet the chairperson's role is vital in leading the change for recruiting and evaluating candidates and their commitment to the board with diversity and governance in mind. Our study also sheds light on the multifaceted reasons why women directors appear to be resisting the discourse of gender quotas.

Keywords: board diversity, women representation, board performance, corporate governance, boardroom behaviors

\section{Introduction}

Recently, the composition of corporate boards has been widely debated (Sayce \& Özbilgin, 2014; Singh, Terjesen, \& Vinnicombe, 2008). Motivated by the divergence in findings relating to the links among gender diversity, board effectiveness, and firm performance (Dalton \& Dalton, 2009), this article presents results from a qualitative study, based on interviews with women directors from the top 50 companies in the United Kingdom, United States, and Ghana by exploring their perceptions regarding the role they play in the boardrooms. The 
findings reveal women's personal motives, boardroom development activities, board working relationships, and perspectives on board performance and gender quotas. We unpack the interplay of gender diversity and boardroom performance, as perceived by our participants.

The role of women in top management teams and leadership positions is well documented (Wittenberg-Cox \& Maitland, 2008). A growing literature (McKinsey \& Company, 2010) indicates the potential benefits of women at the board level. However, women still hold few board seats. According to a recent report by Board Watch, only 15 percent of directors in the United Kingdom's FTSE 100 companies are women, and there were just 9.4 percent in the FTSE 250 in 2011 (News Alert, 2012). In the United States, women constitute 16 percent of the directors of S\&P 500 companies (Spencer Stuart, 2010) and in most other countries that figure ranges between 0.1 percent and 15 percent (Catalyst, 2011).

The difficulties involved in improving boards' gender balance have prompted the introduction of new governance guidelines such as the Higgs (2003) report, drawing attention to the need for increased diversity in the United Kingdom, which requires all FTSE 350 companies with less than 20 percent of women on the board to explain their board composition. Some European countries have introduced gender quota legislation (Tatli \& Özbilgin, 2012). In Norway, since 2006, all listed companies must have 40 percent women directors on their board; otherwise, the stock exchange will delist them (Clarke \& Branson, 2010). As the European champion, Norway jumped from having 22 percent of women on boards in 2004 to 28.8 percent in 2006, to 44.2 percent in 2010, as a result of quota legislation. Norway's impressive growth path is followed by that of Sweden (26.9 percent), Finland (25.7 percent), and Denmark (18.1 percent). Although controversial (Forstenlechner, Lettice, \& Özbilgin, 2012), such a "quota” system has proven efficient to boost the number of women on boards.

Quota legislations are often based on the view that the representation of women on boards may significantly affect the governance of companies. One argument is that women's equal participation may enhance company financial performance (Catalyst, 2011), change board behavior, and enhance independence (Adams \& Ferreira, 2009) and proactivity (Westphal \& Bednar, 2005). Most importantly, gender diversity reportedly guards against the "groupthink" phenomenon (Daily, Dalton, \& Cannella, 2003; Robinson \& Dechant, 1997) and can provide greater access to resources and networks (Fray \& Guillaume, 2007; Milliken \& Martins, 1996), create career incentives through signaling and mentoring (Daily et al., 2003; Sheridan, 1995) and enhance public and investor relations and legitimacy (Baysinger \& Butler, 1985). Our study sheds light on the complex relationship between gender diversity and boardroom performance.

Our data are valuable, as it is hard to access boardrooms. Studies on the topic tend to draw on quantitative methods that use narrow proxies for 
performance, such as nonattendance of board meetings (Adams \& Ferreira, 2009). In order to overcome this challenge, researchers have resorted to putative measures of board performance, that is, board observable diversity issues such as race, age, or gender (Milliken \& Martins, 1996). Our research focuses on whether functional diversity such as education, technical abilities, functional background, and nonregulated aspects of diversity such as socioeconomic background, personality characteristics, or values (Milliken \& Martins, 1996) affect board effectiveness. The presence of a small number of women on the board has an insignificant effect on board performance. If women are a minority in the boardroom, they are less likely to challenge their male counterparts. Research also suggests that the chairperson's role is vital in addressing diversity (Kakabadse \& Kakabadse, 2008).

More generally, this paper contributes to the literature on diversity and governance by providing a better understanding of how the relationship between board gender and corporate governance operates. Despite numerous studies on gender issues and corporate performance (Dobbin \& Jung, 2011), the real effects of women directors on corporate governance are still not clearly understood. It is important to probe the factors in board processes that are crucial to board effectiveness. This study extends the literature by providing evidence of key determinants of women's representation and contributions by adopting a relational approach. A relational approach emphasizes interactions between multiple levels of analysis, moving beyond the unidirectional relationship between "cause and consequence" (Özbilgin, 2006), which has largely dominated the corporate governance literature. Such an approach (Özbilgin, 2006; Özbilgin \& Tatli, 2005) offers a unique understanding of how governance structures and individual perceptions and practices interplay in their specific historical and local context and web of relationships.

The study sheds light on the contexts of three countries, of which one is non-Western/Anglo-Saxon. Ghana, however, includes elements of "residual" culture (Bryson, 2008), which, in a dialectic interaction with other societal norms and beliefs, might explain culturally "dominant" aspects of education, career paths, or corporate behaviors.

The article is structured as follows. First, we review theoretical perspectives on the relationships between board diversity and corporation governance effectiveness. The methodology and sample characteristics of the study are then explained. After this, the article offers the key findings and analysis of the results regarding whether and how gender composition of corporate boards matters. The study concludes with a discussion of the implications of our research on literature, practice, and future research. 


\section{Gender Diversity-Board Performance Relationship}

Since Berle and Means (1932) proposed the principal-agent philosophy of the modern theory of the firm, the debate about the way organizations are governed and controlled has been central to corporate governance studies (Fama \& Jensen, 1983; Shleifer \& Vishny, 1997). The traditional agency theory is based on the assumption that in a modern corporation, there is a separation of ownership and management that leads to costs associated with resolving conflict between owners as principals and managers as agents. To mitigate agency costs, the corporation applies a number of corporate governance mechanisms such as laws, contracts, incentives, and monitoring (Jensen \& Meckling, 1976). Despite the influence of agency theory on the board process, a growing body of empirical research casts doubt on its efficacy by focusing on the structural characteristics of boards and their relationship to firm performance (Hillman, Shropshire, \& Cannella, 2007; Roberts, McNulty, \& Stiles, 2005)—in particular, whether the gender issue matters to enforce contracts and minimize agency costs.

Resource dependency theory suggests the appointment of representatives of interdependent organizations as a means for gaining access to resources critical to a firm's success (Hillman \& Dalziel, 2003; Pfeffer, 1972). This theory places emphasis on the role that directors play in securing essential resources for an organization through their expertise and linkages to other institutions (Johnson, Daily, \& Ellstrand, 1996), since they possess human capital (i.e., directors' advice, skills, and expertise) as well as social capital (i.e., the sum of social resources embedded in a social relationship) (Kakabadse \& Kakabadse, 2008). We can view directors' networks as both “social and symbolic capital” (Bourdieu, 1986, 1989); they evidence how the firm can enhance its standing in the eyes of employees, customers, and the public. Thus, a woman who holds an executive role at a company may raise the firm's reputation, even if the firm has not historically been motivated by corporate social responsibility.

Studies that seek to explore the interplay between boardroom diversity and corporate performance need to tackle the issue of dealing with multiple levels, i.e. individual choices and chances (agency) in the corporate context (structures). For example, the application of Bourdieu's theory highlights a further aspect which bridges the "agency-structure" dichotomy. The focus on agency-structure invites a cause-and-consequence perspective, as it repeatedly seeks to identify ways in which one exercises "agentic" capacity in order to exert influence in terms of desired personal or institutionally based outcomes (Bandura, 2002). There are, however, various other related aspects, which a relational, multilevel perspective allows to emerge. Applications of Bourdieu's theory have used dispositions, 
habitus, and field, at the micro, meso, and macro levels, respectively (KaratasOzkan \& Chell, 2010). Ahern and Dittmar (2011) locate Bourdieu within the body of "practice theory," characterized by reenactment between individual action and context. Maclean, Harvey, and Chia (2010, p. 347), however, apply Bourdieu's theory in an "instrumental" manner, to highlight links between power and the "command over resources" as an ultimate form of symbolic capital in corporate governance.

With its emphasis on internal firm resources as sources of competitive advantage, the resource-based approach (Peteraf, 1993) views the board as a resource that can not only supplant its need for other resources but also improve the company's performance. Hence, the board offers a set of capabilities that provide key sources of sustainable competitive advantage. Pfeffer (1972) suggests that the board's size and background of independent directors are important for management of an organization's needs for capital and regulatory compliance. Although the relationship between board and firm performance makes resource dependency theory a key theory in corporate governance (Pfeffer, 1972), there are still issues that one could potentially address by moving away from the concept of the board of directors as a locus of control toward a more multifaceted role determined by a number of environmental factors (Cullen, Kirwan, \& Brennan, 2007). Issues such as board structure, composition, characteristics, and independence conditions become important variables in determining board effectiveness and corporate financial performance. To constitute a source of competitive advantage, the board's human capital pool must have high levels of both skill and willingness to exhibit productive behavior. Diversity and effective board processes can provide sustainable competitive advantage (Kakabadse \& Kakabadse, 2008). Tatli and Özbilgin (2012) have criticized the unidirectional link that has been made between performance and demographics. They propose the creation of a distinction between an etic, that is, a "fixed" and "predetermined" set of notions about diversity, and an emic, that is, a relational and context-specific set of aspects. Emic investigation is particularly important for comparative studies and those that involve more than one context, such as this one.

Singh (2007) has linked human capital theory (Becker, 1964) with resource dependency theory by examining how a board of directors' investment in personal development enhances the benefits for both the individual and the firm. Some feminist studies have focused on the politics of presence of this two-dimensional description of power. It is claimed that social, gender, and ethnic diversity within the institution or board is key to meet the needs and desires of all (Phillips, 1998). Calas and Smircich (1992) have criticized such arguments. They place emphasis on "gendered" approaches used to propagate knowledge within organizational contexts. Britton (2000, pp. 418-419) argues that attributes such as "gender, race or class" are "presumed and reproduced" within organizations, predominantly via a juxtaposition between "masculinity” and "femininity.” However, Ross-Smith 
and Huppatz (2010) have explored embodied cultural capital as an aspect of feminist discourse rooted in prior conceptualizations of power and gender depicted on the body—a vehicle of "carrying the self" (Davies, 1997, p. 3). Power is a key link between the feminist perspective and the corporate governance literature, particularly in terms of the ways in which organizations have used the concept in order to justify equality or access (Sayce \& Özbilgin, 2014). In terms of corporate governance, organizations also have latent power from the viewpoint of the Bourdieuan "habitus," by incorporating the "know-how" or "disposition" of "getting on" or "being in the game” (Maclean et al., 2010).

Finally, the distinction between masculinity and femininity has been prevalent in the corporate governance literature (Machold, Pervaiz, \& Farquah, 2008); namely, there are either "masculinist" ethics, as highlighted in the dominant discourses of resources, or "feminist" ethics, as highlighted in the dominant discourses of relationship and caring. Hafsi and Turgut (2012) argue that board diversity can be a determinant of care toward social issues within a corporate social performance model. Previous literature (Tienari, Vaara, \& Merilainen, 2010) has identified gender-specific traits in terms of corporate boards, while masculinity, in particular, has become part of a prevalent identity, as well as a discourse in terms of board-level executives (Tienari et al., 2010). While gender diversity may challenge masculine domination of boards, the literature cautions us that changes in head counts and representation are important but insufficient conditions for changing power and inequality structures (Sayce \& Özbilgin, 2014). Such theoretical considerations do not avoid the trappings of "essentialism" in typifying feminine or masculine values or traits, which is part of Syed and Murray's (2008) as well as Özbilgin, Beauregard, Tatli, and Bell’s (2011) "cultural” argument. Intersectionality may be a way to address such trappings by further explicating relationships between different levels of analysis and transforming related capitals (Tatli \& Özbilgin, 2012).

In conclusion, corporate governance theories support board diversity on the basis that a diverse board operates to reduce agency costs, facilitates access to untapped resources and networks, and improves performance. Building on Boxall's (1996, p. 67) claim that the resource-based view of human resource advantage (i.e., the superiority of one board over another) consists of the potential to capture a supply of exceptional human talent and human process (i.e., "causally ambiguous, socially complex, historically evolved such as learning, cooperation, and innovation"), we explore whether gender diversity in the board contributes to boardroom process advantage. 


\section{Empirical Literature on Gender Diversity and Firm Performance}

Although there are various theories relating to the impact of board diversity on board performance, the empirical literature is largely inconclusive. The major debate on the value of board diversity within management is on corporate performance. These are predominantly quantitative studies that test for a relationship between board diversity and various measures of profitability and stock valuation (Kramer, Konrad, \& Erkut, 2006). Gender diversity has been viewed as an asset toward reducing agency costs and improving corporate performance. Many US studies (Adams \& Ferreira, 2009; Hillman et al., 2007) have found a positive relationship between the representation of women on the board and stock return. Some studies have attempted to explain this positive correlation. Extending Baysinger and Butler's (1985, p. 114) argument that “topperforming firms may be willing to invite independent directors on to their boards in order to appear progressive," companies may appoint women directors when the board believes it can afford to have a woman on the board. Ryan and Haslam (2007), however, argue that companies are more likely to appoint women to leadership positions where change is required.

There are numerous studies that find either no effect of board diversity on financial performance or find negative effects (Brickley, Coles, \& Terry, 1994; Rhoades, Rechner, \& Sundaramurthy, 2000). The missing moderator variables might explain the inconclusive evidence with respect to the influence that female directors actually have on the board (Miller \& Triana, 2009). Judge (2003) argues that although having more women on boards is generally regarded as positive, in fact, women leaders can also have a negative impact on performance (Haslam \& Ryan, 2008). Examining FTSE 100 companies during the period 2001-2005, Haslam, Ryan, Kulich, Trojanowski, and Atkins, (2010) conclude that companies with male-only boards achieve higher valuation than those with a woman on their board due to the perception that poorly performing women may lead to a firm's negative valuation. Furthermore, despite the positive initiative for Norwegian public companies to include women on boards, a recent study found that such firms had a decrease in profitability (Matsa \& Miller, 2011) and value (Ahern \& Dittmar, 2011).

There is no consensus on the effect of gender diversity on corporate performance with respect to studies using panel data. However, these studies are of limited value, as they do not report what transpires within a boardroom and do not measure each director's individual contribution to the decision-making process (Adams \& Ferreira, 2009). Moreover, these studies have not examined genderbalanced boards because they are rare. Overall, studies are relatively silent on the 
mechanisms that cause diverse boards to perform differently (Hoogendoorn, Oosterbeek, \& van Praag, 2011).

The use of a qualitative method helps us gain an in-depth understanding of whether and, if yes, how women directors make a difference to board effectiveness. In particular, this study draws attention to the role of the chairperson with respect to the contribution of women in the boardroom, as well as boardroom behavior and dynamics. In addition to adopting a relational perspective, we employ insights from resource-based theory, behavioral theory on boards, and corporate governance (Cyert \& March, 1963), as well as from research on social representational theory, namely, justice, resources, and interests (Phillips, 1998).

\section{The Study}

The inconclusiveness of prior quantitative research on board diversity and performance is the main factor that has led us to adopt a qualitative study involving 30 interviews with women directors. This approach allows us to explore complex issues that have human interaction at their core (Culpepper \& Gilbert, 1999) by seeking views from board insiders, and to establish what impact respondents think board diversity has on processes and corporate governance.

English is spoken in the three selected countries; this has eliminated the need for translation services and potential loss of meanings. In Ghana, English is the language of the former colonial structure and remains one of the official languages. Language can be part of the perceived "residual" culture (Bryson, 2008). In interaction with other norms and values (which might even be antithetical to it), it may contribute to the formation of symbolic capital in this context.

In terms of sampling, the top 50 publicly listed companies in the United Kingdom, United States, and Ghana have been targeted. These countries display different levels of gender-related development (as per the Gender-related Development Index [GDI]) and gender inequality (as per the Gender Inequality Index [GII]), and also exhibit differences in terms of their institutional, market, and business sophistication (United Nations Development Programme [UNDP], 2012).

The reason for this selection is twofold. First, we want to find out whether there are unique boardroom behaviors among an elite set of female directors who sit on boards of top companies in both advanced (i.e., the United Kingdom and United States) and developing economies (i.e., Ghana), in terms of business and market sophistication (UNDP, 2012). Although the inequalities in achievement between women and men in the selected countries as captured by both indexes are 
significant, all three economies operate under the same corporate governance regime, namely, shareholder orientation. The second factor is data accessibility. We share Schwandt's (2000, p. 202) thoughts that "the idea of acquiring an 'inside' understanding ... is a powerful central concept for understanding the purpose of qualitative enquiry."

Difficulties were encountered in reaching potential respondents (see Table I). The population is small, and high levels of trust are required to initiate contact with these women and discuss sensitive topics (Atkinson \& Flint, 2004; Rhodes, Kling, \& Johnston, 2004).

[Insert Table I about here]

Building on the output of research programs over the past 20 years, we established contacts with top listed companies and were given access to an elite of female directors. We used a "snowballing" sampling method, a link-tracing technique that relies on a series of referrals within a circle of people who know each other or are loosely connected, to obtain a wider range of research contacts, in order to provide an account of meanings and activities from inside the unknown (Atkinson \& Flint, 2004). The selection of samples is based on insider knowledge and referral chains among subjects who possess common traits that are of research interest (Kaplan, Korf, \& Sterk, 1987).

We interviewed female board members with whom we had direct or indirect personal or professional contacts. A chain referral technique improved our access, as a director's referral to colleagues provides a level of trust and a perception of being an insider. This is especially important when respondents are asked to comment on sensitive topics ranging from their behavior and performance and those of their colleagues, to their views about their contributions.

We conducted semistructured interviews of 60 minutes each, on average. The interviews were intended to collect the perceptions associated with women directors' experience and contribution in the boardroom. We use extracts that allow us to identify a set of transverse generic themes. The respondents have boardroom experience spanning from 4 to 14 years. Some have held simultaneously as many as seven board positions, including charities and nonlisted companies, while others have held only two board positions. Before the interview, participants were informed about the nature and reason for the meeting. They were assured of confidentiality, concerning both personal details and the companies on whose boards they sit. Due to a small population and to protect the company and/or individual's possible identification, we cannot make reference to the sectors in the sample.

There was virtually no hesitance or concern among the interviewees. It is worth noting that all of our respondents are individuals who often interview. Any noted differences in response style were certainly contextual. In addition to asking 
respondents to discuss their experiences, we asked them to verify biographical information such as race, ethnicity, and board role. We tape-recorded and transcribed some of the interviews, while we captured others by note taking, to accommodate the various degrees of respondents' comfort zone.

The approach to data analysis followed the model of conversation analysis (Atkinson \& Heritage, 1984). The collection and transcription processes were ongoing, with regular meetings between coauthors to discuss individual interviews. These sessions were open-ended, with themes emerging as the outcomes of our agreement. Our approach is interpretive data analysis where every inference is rooted in specific textual evidence of collected narratives, whether they are transcripts or interview notes (Denzin, 1989).

Ewick and Silbey (1998, p. 29) observe that what "people tell about themselves and their lives, both constitute and interpret those lives." Our approach was a bottom-up analysis, and to analyze the interview transcript, we used the method of idea concentration, namely, thematic analyses (Kvale, 1996). This method consists of identifying main ideas and themes and singling out essential information. Data were sorted into five categories. Our results represent only views of our sample and offer "native" insights for subsequent testing.

\section{Findings and Analysis}

Our thematic analysis of interview transcripts and notes produced insightful findings regarding five main influences of women directors on board processes and dynamics: necessary resources, boardroom development, work relationships in the boardroom, contribution and board performance, and boardroom quotas. The combination of these categories describes a board's behavioral dynamics, upon which the actual board effectiveness depends, while taking into account how the web of interpersonal and group relationships between men and women directors develops (Roberts et al., 2005).

\section{Necessary Resources}

Although the progress of women on the board has been slow, considerable change in attitudes has taken place in the past 15 years. Respondents commented that companies are making efforts to diversify their boards toward true fairness.

Culturally, it is far more difficult for a woman at all levels to succeed professionally. High power distance and tribal ties are still very strong. ... I was motivated and had the right skills and right connections to be invited to this board. (P8, Ghana) 
The Ghanaian family structure provides for a large network of kinship relationships. People usually feel obliged to help kinship emotionally or through cultural expectations and, as such, tribal ties are an effective lever that women can use to gain boardroom access. However, during the past decade, the right skill set is also becoming almost as important. Although the filial ties appear less important within the US context, having a good education and an effective network constitute an advantage. One respondent added:

Women need a good education, both academic and on-the-job training in corporate level jobs as well as good networks. Usually, someone from your network will recommend you to a president or invite you on their board. (P11, United States)

In addition to her Harvard education, P11 made use of her father's gubernatorial network to gain her first board post. When we inquired whether her father's position had been an advantage to secure her first board role, she replied "in a way," but was quick to point out that she was already a high-flying executive.

In the United Kingdom, one participant noted that high motivation, effective networks, and financial skills are critical for women's entry to the board.

To be attractive to the boardroom, a woman needs to have the right skill set and a sound network and take time to listen and learn. I think that a woman with financial skills is more likely to be invited into the boardroom. (P3, UK)

A strong network is a valuable resource that women can exercise in order to open the boardroom's doors. A participant noted: “There are many talented women ... but without the sound networks, they often cannot see the way forward on how to fulfil their own ambition” (P4, United Kingdom). Ghanaian participants are aware of their privileged position in society and are open about their advantage as a result of foreign-based education (predominantly in the United Kingdom and United States). They acknowledge that their success is to a great extent due to their filial ties and social standing, but "one must be motivated to take advantage of the opportunities and be prepared to work hard." (P12, Ghana)

In the United Kingdom and United States, participants do not talk openly about privilege or education networks. Only after some probing did some acknowledge that having a privileged background helps open the boardroom doors. While some tried to deny that their background was an advantage, one UK participant added, "It is difficult to know whether one's background is an advantage or disadvantage. It very much depends on the context" (P30, United Kingdom). Whether explicitly or implicitly stated, the necessary resources that a woman needs to have in order to penetrate the boardroom are commitment, an effective network, and sound education. 
Emphasis regarding resources varies among participants, as well as the examples that provide dimensions to these properties-consistent/inconsistent, filial/educational, privileged/common. Although commitment and education are necessary criteria for recruiting women directors, the recruiting process is nonetheless predominantly through personal recommendation, which requires networks.

Supporting the preceding is Higgs's (2003) and Tyson's (2003) findings that almost half of the directors that they surveyed in the United Kingdom had been recruited through personal friendships and contacts. Only 4 percent had a formal interview, and only 1 percent obtained the role through answering an advertisement. Cross-national differences are not significant, particularly regarding properties. There is a noted difference between candidates in terms of order of importance (e.g., network or commitment) but not between different national contexts. In terms of networks, filial networks appear to be more predominant in Ghana, while educational networks seem to be more prominently reported in the United Kingdom, with the United States providing a mixture. The necessary resources for boardroom entrance are defined as commitment, network, and education along the spectrum of their dimensions (consistent/inconsistent, filial/educational, privileged/common).

\section{Boardroom Development}

Privileged education and experience may open the boardroom door, but these do not necessarily prepare one for performance. The need to develop human capital at the board level for improved performance has been recognized; however, the alignment between the skills represented on the board and those required by its strategic intent is not always effectively pursued. The actual level of human capital (i.e., board directors) changes over time and thus requires monitoring for its match with the board's strategic needs. Yet our participants indicate that boards often do not have a budget for directors' development and that development is "by doing," while large budgets are allocated for management training and development: "From my experience, the boardroom usually does not have budgets for directors' training” (P4, UK).

One participant stated, "To improve upon boardroom performance, there is a need for boardroom education, both academic and on-the-job mentoring and coaching” (P11, United States).

Participants perceive boardroom development as a very important, necessary activity that has been underresourced and often ignored. They expressed the need for directors' formal development through education and training, as well as coaching and mentoring. Some stated that development budgets for directors are not available due to the expectation that they already have the necessary skills 
and capabilities for the boardroom. Others held the view that because they were not permanent employees, corporations do not feel obliged to invest in their development. Absence of development activities may affect women, the nontraditional and new participants of the boardroom, more negatively than it does men. A number of participants asserted that "mentoring" provided one such alternative mechanism for development, particularly important for women and minorities. One director commented, "Having an understanding mentor who is also board chairman has been tremendous help for my effectiveness at this board (P23, Ghana).

\section{Work Relationships in the Boardroom}

Women directors who make it to the board have already demonstrated their knowledge, skills, and capabilities. Yet, they appear to need to gain credibility before they can be accepted. Once women enter the boardroom:

It takes time for women to establish their credibility on a board and understand how that board works. ... A newcomer needs to understand the rules and conversation of what is spoken and what is not said, and that takes time. (P5, United States)

Gaining credibility is equally important for women on Ghanaian boards: "I think that it does not matter how you get to the board. What counts is what you do once you are there” (P27, Ghana).

For UK participants, in addition to credibility and interpersonal skills, there is a need for "women to be capable of fitting in with the culture and at times almost be chameleon-like. They need to modify their approach and use their emotional intelligence to deal with different situations and build relationships” (P15, UK).

Institutionally, individuals can view board directors as "over-socialized actors," either following certain cognitive, normative, and regulatory patterns or complying with the rules and the logic of each particular board (DiMaggio \& Powel, 1983). Moreover, research suggests that there is a significant cohesion among corporate elites' "inner circles," formed by board directors (Domhoff, 2002). Our participants are aware that men and women need to grow accustomed to each other in the boardroom setting. It is not as much a power play, although power is always present, but "rather getting used to the new reality and being comfortable with it" (P28, UK) - this is a common explanation of working relationships in the boardroom. "Board culture is peculiar-it is formal but always cordial, and nobody ever is cutting each other off, and so you must pay attention not to be totally off the page in how you interact with others ...” (P14, UK). One does not challenge one's colleague at the board meetings, as those relationships are cordial, but often fragile. According to a UK participant, "This gives [him/her] 
an opportunity to prepare a response. You do not want to embarrass your colleague and look bad as a result of being caught off-guard” (P15, UK).

In the United States, the CEO/chairperson is a pivotal figure on the board with full board control and is the first point of call. One participant explained:

I will raise it with the CEO/chairman beforehand. You don't just throw a bomb into the room. More often than not, the $\mathrm{CEO} /$ Chairman will raise the issue and ask for board comments. (P7, United States).

Differences between what people say and what they actually mean is common (Hatch, 1997). Women need to be capable of fitting in with the culture and modifying their approach to deal with different situations. Since some male directors in previously homogeneous boards may feel uncomfortable working with female colleagues, many women directors often feel a need to prove themselves in order to gain acceptance. According to one participant:

The best advice I can give is you have arrived. You do not need to prove anything anymore. Just sit back, observe others, and learn. Once you understand the issues, question [them] in the contextually acceptable manner. (P26, UK)

The respondents underscored that they need to learn to fit into the board environment and blend with male colleagues. Literature suggests that devoting sufficient time to the boardroom role and an appropriate amount of time to learning is necessary to be able to contribute (Forbes \& Milliken, 1999; Nadler, 2004). Many respondents have recognized this and have chosen not to express their views initially to avoid possible conflict. Even the tone of voice is important in the boardroom. This interesting insight is a good example of the "embodiment" aspect, as scholars have previously highlighted (e.g., Davies, 1997).

Any woman that enters the board is treated with a good dose of suspicion. ... One needs to be diligent, patient, and have a voice coach. A woman with an overly feminine, piercing, and shrill voice is never really accepted on the board even if she has a supportive chairman. (P30, UK)

Women often feel the need to fit in due to the low female representation in boardrooms. New women on the board are entering a new culture and therefore feel they need to adjust their behavior. To make the board a more comfortable place for women requires considerably more women to be present on the board. "Having more women on the board does not mean that you have a closer relationship with the other woman or women, but rather that it is more difficult to ignore 30 or 40 per cent of the board members” (P28, United States).

Kramer et al. (2006) suggest that women as a minority on the board have experiences of others not listening to them and exclusion from socializing and even from decision making; additionally, they have been subjected to 
inappropriate behaviors, which indicates that male directors notice their gender more than their individual contributions. A chairperson's sensitivity and skills impact on both board relations and contribution:

It is the sensitivity of the chairman to diversity and his skills to create space in meetings for everyone to contribute that creates positive relationships. Managing the interaction between highly opinionated people is a real skill. (P27, Ghana)

To contribute to board dynamics, women directors need to understand not only the board's rules and regulations but also other directors through the interaction with other members (see Table II). It is only through deliberative dialogue that members can meet both needs in heterogeneous boards, in order to accommodate different perspectives (Kakabadse, Kakabadse, \& Knyght, 2010).

[Insert Table II about here]

A powerful chairperson and/or CEO or other directors with unique resources can exercise power within the board whether for a perceived good or not. Power is a concept that is unavoidably value dependent, as "both its definition and any given use of it, once defined, are inextricably tied to a given set of (probably unacknowledged) value-assumptions which predetermine the range of its empirical application" (Lukes, 2005, p. 30); similarly, they would be able to induce "mobilization of bias" (Rodrigo, 2005) by promoting particular values, opinions, board culture, rituals, and procedures.

\section{Contribution and Board Performance}

It is only through the processes of communicative interactions that women can have board impact, which may later amplify to transform the patterns of dynamics and ultimately board performance (Kakabadse, Kakabadse, \& Barratt, 2006; Stacey, 2007). In practice, however, "the impact of women directors on board effectiveness is differential, depending on whether they can raise sensitive issues successfully ... and challenge their colleagues in a supportive way” (P17, United Kingdom). The ways in which women directors engage in board interactions can have important implications for processes and dynamics. One female director explained that:

Having a diverse board is important. People are forced to listen to the views of others, but these views often need to be moderated by a steady-handed chairman. Only then can those dialogues lead to more effective decisions and, in turn, enhanced corporate performance. (P1, Ghana)

However, to make a value-added contribution, a UK respondent noted: 
One has to have something special, one's personal kind of magic. ... That is, you need at least one thing that distinguishes you from others ... that builds your brand and creates value. (P4, UK)

The importance of effective dialogue is emphasized by many participants as it is the main lever for direct contribution:

Although the board climate was positive, I still had to convince my colleagues of my principles. It paid off. We now talk about social benefits. (Ghana, P23)

Access to the chairman's attention, knowledge, and memory, which in turn influence the perception or "framing" of the problem situation, is a valuable resource that women directors need (Lindenberg, 2003). Participating in the early strategic decision-making stages enables women directors to influence the desired outcome (Rindova, 1999).

Prior literature (e.g., Kramer et al., 2006) has stressed that women make a difference in the boardroom by a collaborative leadership style characterized by increased listening, social support, win-win problem solving, bringing new issues and perspectives to the table, and broadening the content of boardroom discussions, as well as by asking tough questions and demanding direct and detailed answers. It is in that vein that some view gender diversity as enhancing debates (Campbell \& Minguez-Vera, 2008). Nonetheless, this is actionable only if the board has an effective chairperson. In the view of one female director, diverse boards can be more effective due to "women's effect on board dynamics. Women have different experiences and are more likely to see problems from different perspectives and often in a more creative way” (P10, Ghana). One US female director feels strongly that:

The CEO/Chairman is the key in terms of women contributing fully, by being even handed in taking contributions from all board members. It is the chairman that makes the board effective or not. (P9, United States)

Participants view the chairperson (CEO/chairperson in the United States) as vital in supporting the participation of women directors toward board effectiveness. Prior literature and praxis have recognized the chairperson's role in promoting gender diversity (Davies, 2011). Board leadership is critical, as it sets the tone for meetings, behavior expected, and willingness of board members to listen to each other (Kakabadse \& Kakabadse, 2008). Most importantly, it ensures a culture for contribution. As one participant noted, "Diverse boards are definitely more effective, provided they have a chairman that has sound boardroom skills ... (so that) a more penetrating dialogue is assured" (P15, United Kingdom).

Additionally, "the role of the chair is crucial for all directors, but even more so for women and ethnic minorities. An effective chairman invites comments, solicits input, and gives visual cues of contact and interest” (P8, Ghana). 
Ghanaian directors emphasize the importance of an effective chairperson. One added:

Effective boards work within a regulatory framework but create their own shared understanding specific to the organization that they govern. They develop their own rules of engagement with executives, regulators, and market, as well as form diversity among other things. (P10, Ghana).

Essentially, women's contributions are likely to differ in response to each board's idiosyncratic circumstances and each chairperson. The chairperson can play an important role in identifying and focusing issues that require women directors' attention. If the chairperson does not pay attention to effective integration of women, it can be very frustrating for those women to take part in and consequently achieve a contribution to board effectiveness. It is the chairperson's responsibility to create space in meetings for everyone to contribute and manage the interaction between a group of highly opinionated people (Kakabadse \& Kakabadse, 2008).

To contribute to company performance,

Boards tend to focus predominantly on a shareholder perspective rather than taking a holistic perspective on business. Soft issues are often overlooked, and I think that diverse boards are more effective in dealing with softer but fundamental issues, such as employee working conditions and business ethics. ... Women are more innovative and are likely to find creative solutions to posed challenges' (P12, Ghana).

This is supported by research that shows how women in leadership roles are more likely to foster innovation and creativity in the organizations they lead (Idris, 2009).

The emergent consensus among study participants is that diverse boards are more likely to have more open dialogue and to be concerned about stakeholders (Table III). However, there is no single practice to make the board effective due to the idiosyncratic nature of boards (Kakabadse et al., 2006, 2010).

[Insert Table III about here]

\section{Gender Quotas for the Boardroom}

Although the need to have more women on boards has been acknowledged (Catalyst, 2011), the participants offered a negative view on the effect of quotas on board performance:

Quotas undermine these women who worked very hard to get where they are now. Organizations can widen the pool of talented 
individuals suitable for board positions by grooming women first $\ldots$ and actively encouraging talented women to find roles as NEDs with other organizations. (P16, UK).

This resonated with female directors from Ghana, who held that "the problem of female underrepresentation on the board cannot be solved by a quota system. We need a systemic education from the bottom up" (P26, Ghana). An American counterpart also rejected the notion of quotas: "No, definitely no quotas! Quotas would undermine our achievements” (P25, USA). Despite awareness that quotas could accelerate progress and reduce gender discrimination in the long term, many participants felt that quotas would hinder the efforts toward board effectiveness. This supports the argument that quotas bypass competitive processes and in turn sideline the merit principle that ensures the best person for the job (Dahlerup, Freidenvall, Stolt, Bivald, \& Persson-Weiss, 2008). Yet some researchers demonstrate that resistance to quotas emanates from a culture of resistance against women's full participation to positions of power and authority and that quotas and merit may indeed complement each other (Forstenlechner et al., 2012; Sayce \& Özbilgin, 2014). Participants talked extensively about the importance of competence-based selection because they do not want to be in a situation where female differences in the boardroom are due to lesser qualifications and less ability, which could in turn devalue their achievement (Table IV). Singh et al. (2008) examines human capital of the newly appointed directors in an FTSE 100 firm and shows that female directors possess similar human capital to their male colleagues and contribute to the positive return on investments. The respondents expressed that they should be viewed as having gained their positions on merit. Moreover, they took pride that their hard work has changed attitudes about women in the boardroom and has served as a role model to aspiring women.

Participants also recognized that their single voice on the board limited their contribution and that an increased female representation is imperative:

I feel that my contribution is limited. It's a limitation because the board has a relatively singular perspective on the world and because board diversity is symbolic. I am the only woman on the board. (P19, United States).

[Insert Table IV about here]

Understanding women's responses and resistance to quotas requires us to understand how the "field" operates. Masculine boardroom domination means that women join as outsiders, only to accept rather than challenge male norms, one of which remains the idea that merit, competence, and performance of the board are free from gender bias. Bourdieu's theory of symbolic violence, referring to the tacit and unconscious forms of domination in which the subjugated may uphold discourses and at the same time disadvantage their social group, may account for 
women's resistance to quotas. Bourdieusian framing may be particularly pertinent as gender quotas are reported to enhance rather than diminish meritocracy.

From the data, we understand that women on boards are conforming to the rules of the field and utilizing the given paths of development, communication, and expressing their career goals and the ways in which to reach them.

Nonetheless, they also exhibit a very strong developmental orientation. This is evidenced in the ways they stress not only the procedural aspects (tacit or explicit) of board-related interactions, but also the learning and development orientation of their relationships and work processes, including advancement of the relevant human capital. This can also be one of the major ways in which women are reshaping the field, as organizational actors. Such a contribution can, in effect, shape and benefit the board in several ways, particular future achievement.

\section{Conclusions}

The corporate governance literature suggests the benefits of board diversity, but relevant studies remain inconclusive on whether increased gender diversity results in improved performance. Evidence-based literature still, largely, fails to understand the real practices of women board directors. This gap has led us to conduct interviews with women in the boardroom. The research draws attention to female practitioner perspectives, based on their experience and interrelationship with male colleagues. The study addresses, in particular, the factors that hinder or help promote board gender diversity, as well as the extent to which women directors can fully contribute to corporate governance efficacy.

The research frames the attitudes, behaviors, and skills of women directors in three categories: quotas, supportive contributors, and serious players. In relation to each of them, we identify the obstacles for women to be effective on the board and, in particular, the role of the chairperson in informing such effectiveness.

The study reveals that the participating companies have not adopted a strategic approach to managing gender diversity on the board. Women directors behave differently from their male counterparts; when they are in leadership roles, they are subject to close scrutiny (Ryan, Haslam, Hersby, \& Bongiorno, 2011). They tend to remain friendly and supportive with the fear of marginalization, while men can show assertiveness in the absence of such a group threat. Compliance with the logic of the field provides a route for women to gain access, credibility, and development.

Overall, our respondents regard board diversity as an important goal worth pursuing and note that it is particularly relevant in candidate selection. Participant rationales that justify board diversity fall into two broad categories: (1) a 
functional category that relates to corporate performance and (2) a representative category that relates to employee motivation and customer loyalty. The argument perched on corporate performance emphasizes that boardroom discussion is richer, while creativity and different perspectives are more productive, with a diverse group of directors that in turn reduces the likelihood of uncritical "groupthink." Such a group of directors can also bring access to different resources. These findings echo other scholars' arguments that diversity can increase creativity and innovation and can improve problem solving (Daily \& Dalton, 2003; Robinson \& Dechant, 1997).

Our results highlight the importance of increasing the number of women directors in the boardroom, but not through quotas. All of our respondents agree that board diversity is good, as it brings a mix of skills and background and makes it more effective. However, they fear that enforcing board gender quotas could ultimately undermine the value that women directors create. The respondents present themselves as individuals who have been selected on the basis of their merit. Despite the general alarm of our participants about the possible negative consequences of quotas, research identifies that quotas do not have to contradict with competence and merit-based systems (Forstenlechner et al., 2012; Tatli, Vassilopoulou, Ariss, \& Özbilgin, 2012). The participants' responses may be the result of dominant discourses of resistance against women's full inclusion in the boardroom, which are not only practiced by men but also by women, who have achieved their success in the context of male domination. The findings also reveal the chairperson's role in promoting women's engagement as a way of recruitment and evaluation of their commitment to the board. The sudden demand for women directors gives respondents an opportunity to choose a board where they feel they can obtain the chairperson's support and add value.

One of the major contributions of the article is the theoretical and empirical extensions of previous discussions on board gender diversity, which go beyond direct relationships with financial performance, by focusing on real practices. As previous studies have shown (Finkelstein \& Mooney, 2003), board processes are key to board effectiveness. However, as Pye and Pettigrew (2005, p. 32) poignantly point out, the "contextual fabric ... reflects very differently on the choices made by directors and boards in their doing of corporate directing and any subsequent judgments of effectiveness." Boardroom diversity is not always directly related to corporate performance, but rather to the quality of decisions. Thus, this article fills a gap in the gender diversity literature by highlighting some of the benefits of a more gender-balanced board, and contributes toward a richer understanding of the multiple levels of interactions between social actors and structures in the study of women on boards and gender as a factor of diversity. The findings suggest a range of implications for practitioners. First, there is a need to evaluate the efficacy of recent regulations on board diversity. Second, it is important to encourage women respondents through education, mentoring, and 
networking. Whatever the reason (e.g., structural or cultural), there are still relatively few women who have "reached the top" in the corporate world. Moreover, those who have reached the top enjoy their privileged status and are protective of it. Our study therefore supports the argument that there may be continuity of culture of privilege and power, in the context of changes in demography and representation (Sayce \& Özbilgin, 2014). Our respondents shared many subtleties, social niceties, and latent power that may be key elements in linking the transnational elite, despite differences in countries' GDI, GII, and other rankings. The relevance of this finding would benefit from more theoretical development, particularly on the discussion of the interweaving issues of the transnational female elite's power.

The results from our study suggest that there is a need for further research on board diversity, including qualitative research, to address methodological limitations of previous studies. Although women directors need to have the power or capability to act independently, there is little understanding of how women directors deal with hidden meanings, silence, embedded norms and values, and invisible power relations in the boardroom, as well as how they exercise their power or, in some cases, construct political coalitions (Pettigrew \& McNulty, 1995).

The extant literature suggests that financial benefits of diversity should not be the only driving force and therefore should not be overstated. Future studies should examine the real benefits of board diversity and the mechanisms or processes that can help women identify and develop their talent and fulfill their ambitions. The viewpoints from institutional investors and male counterparts are also relevant to assess the advantages and disadvantages of board diversity. In future research, such stakeholders could also be included as part of a relevant sample. Our results suggest that there are nonfinancial benefits relating to board diversity such as important signaling to stakeholders, enhancing corporate reputation, role modeling, changing patterns of boardroom decision making, and, above all, making full use of available talent. Finally, the conclusions of our study add to the body of the resource-based theory, by extending it to boardroom relations. This research contributes to the understanding of how female directors' resources, such as skill as networks, together with their career orientation to participate in the boardroom, contribute to the increase of their presence on organizations' boards.

Nada K. Kakabadse is professor of policy, governance, and ethics at the Henley Business School, University of Reading, and visiting professor at US, Australian, French, Kazakhstani, and Chinese universities. Nada is an elected, active member of the European Academy of Science and Arts (EASA) and head of its EU Representation Office, Brussels. She has coauthored 19 books and has published over 190 scholarly articles. Her current areas of interest focus on leadership, boardroom effectiveness, governance, CSR and ethics, diversity, entrepreneurship, ICT impact on individuals and society, and the policy design of the state. 
Catarina Figueira is director of the Cranfield Centre for Economic Performance and Policy and reader in applied economics at Cranfield School of Management. She was a former director of the Cranfield Executive MBA program. Her research interests lie in the area of corporate performance analysis, namely, efficiency and productivity issues and the assessment of regulatory reforms. Catarina has published in leading international journals and is a frequent contributor to international conferences. She has advised the OECD and the European Commission as well as a number of financial institutions. Catarina is editor of the Research Paper Series of Cranfield School of Management.

Katerina Nicolopoulou is a senior lecturer at Strathclyde Business School. Her research expertise is in social, sustainable, and diversity aspects of entrepreneurship and innovation. She is a member of editorial teams of peer-reviewed scientific journals, a fellow of the UK Higher Education Academy, as well as an international jury member for awards in sustainability and CSR. Her publications include the coedited volumes Global Knowledge Work: Diversity and Relational Perspectives (Edward Elgar, 2011)and Corporate Social Responsibility and Human Resource Management: A Diversity Perspective. Her latest book with Routledge Publishers will be on the topic of sustainable entrepreneurship and social innovation.

Jessica Hong Yang is a lecturer in accounting at Henley Business School, University of Reading. She holds a PhD in corporate governance. Her research interests include board diversity, executive remuneration, transparency and accountability, and social and environmental reporting. She has published in a wide range of academic journals and books. She is a chartered accountant and a fellow of the Association of Chartered Certified Accountants.

Andrew P. Kakabadse is professor of governance and leadership at Henley Business School and emeritus professor, Cranfield School of Management. He is vice chair of the Supervisory Board of the Academy of Business in Society and visiting professor at the University of Ulster. Andrew's research covers boards, top teams, and the governance of governments. He has published over 40 books, 88 book chapters, over 235 articles, and 18 monographs. Andrew is coeditor of Corporate Governance: International Journal of Business in Society.

Mustafa F. Özbilgin is professor of human resource management and organizational behavior at Brunel Business School, London. He also holds two international positions: co-chaire management et diversité at Université Paris Dauphine and professor of management at Koç University, Istanbul. His research focuses on equality, diversity, and inclusion at work from comparative and relational perspectives. He has conducted field studies in the United Kingdom and internationally, and his work is empirically grounded. His work has a focus on changing policy and practice in equality and diversity. He is an engaged scholar, driven by values of workplace democracy, equality for all, and humanization of work.

\section{References}

Adams, R., \& Ferreira, D. (2009). Women in the boardroom and their impact on governance and performance. Journal of Financial Economics, 94(2), 291-309.

Ahern, K. R., \& Dittmar, A. M. (2011, May 20). The changing of the boards: The impact on firm valuation of mandated female board representation. Retrieved from SSRN, http://papers.ssrn.com/sol3/papers.cfm?abstract_id=1364470

Atkinson, J. M., \& Heritage, J. (Eds.). (1984). Structures of social action: Studies in conversation analysis. Cambridge, England: Cambridge University Press. 
Atkinson, R., \& Flint, J. (2004). Snowball sampling. In M. S. Lewis-Beck, A. Bryman, \& T. F. Liao (Eds.), The SAGE encyclopedia of social science research methods (pp. 10431044). London, England: Sage.

Bandura, A. (2002). Social cognitive theory in cultural context. Applied Psychology: An International Review, 51(2), 269-290.

Baysinger, B. D., \& Butler, H. N. (1985). Corporate governance and the board of directors: Performance effects of changes in board composition. Journal of Law, Economics, and Organization, 1(1), 101-124.

Becker, G. S. (1964). Human capital. New York, NY: Columbia University Press.

Berle, A., \& Means, G. (1932). The modern corporation and private property. New York, NY: Harcourt, Brace.

Bourdieu, P. (1986). The forms of capital. In J. G. Richardson (Ed.), Handbook of theory and research for the sociology of education (pp. 241-258). New York, NY: Greenwood.

Bourdieu, P. (1989). Social space and symbolic power. Sociological Theory, 7(1), 18-26.

Boxall, P. (1996). The strategic HRM debate and the resource-based view of the firm. Human Resource Management Journal, 6, 59-75.

Brickley, J. A., Coles, J. L., \& Terry, R. L. (1994). Independent NEDs and the adoption of poison pills. Journal of Financial Economics, 35(3), 371-390.

Britton, D. (2000). The epistemology of the gendered organisation. Gender and Society, 14(3), 418-434.

Bryson, J. (2008). Dominant, emergent and residual culture: The dynamics of organizational change. Journal of Organizational Change Management, 21(6), 743-757.

Calas, M., \& Smircich, L. (1992) Using the "F" word: Feminist theories and social consequences of organizational research. In A. J. Mills \& P. Tancred (Eds.), Gendering organizational analysis, 222-234. London, England: Sage.

Campbell, K., \& Minguez-Vera, A. (2008). Gender diversity in the boardroom and firm financial performance. Journal of Business Ethics, 83(4), 435-451.

Catalyst. (2011, February). Women on boards. Retrieved from http://www.bis.gov.uk/assets/biscore/business-law/docs/w/11-745-women-on-boards.pdf

Clarke, T., \& Branson, D. (Eds.). (2010). Handbook of corporate governance. London, England: Sage.

Cullen, M., Kirwan, C., \& Brennan, N. (2007, May 10-11). Comparative analysis of corporate governance theory: The agency-stewardship continuum. 20th Annual Conference of the Irish Accounting and Finance Association, Institute of Technology, Tralee.

Culpepper, J., \& Gilbert, T. T. (1999). Evidence and ethics. Lancet, 353, 829-831.

Cyert, R. M., \& March, J. G. (1963). A behavioral theory of the firm. Englewood Cliffs, NJ: Prentice Hall.

Dahlerup, D., Freidenvall, L., Stolt, E., Bivald, K., \& Persson-Weiss, L. (2008). Women’s rights and gender equality. Stockholm, Sweden: WIP, Women in Politics Research Centre, 
Department of Political Science, Stockholm University, for European Parliament's Committee on Women's Rights and Gender Equality.

Daily, C. M., \& Dalton, D. R. (2003). Women in the boardroom: A business imperative. Journal of Business Strategy, 24(5), 8-10.

Daily, C. M., Dalton, D. R., \& Cannella, A. A. Jr. (2003). Corporate governance: Decades of dialogue and data. Academy of Management Review, 28(3), 371-382.

Dalton, D. R., \& Dalton, C. M. (2009). Women gain (hidden) ground in the boardroom. Harvard Business Review, 87(1), 23.

Davies, A. (2011). Women on boards. London, England: Department of Business Innovation and Skills, Equality and Human Rights Commission.

Davies, K. (Ed.). (1997). Embodied practices: Feminist perspectives on the body. Thousand Oaks, CA: Sage.

Denzin, N. K. (1989). Interpretive interactions. Thousand Oaks, CA: Sage.

DiMaggio, P. J., \& Powel, W. W. (1983). The iron cage revisited: Institutional isomorphism and collective rationality in organizational field. American Sociological Review, 48, 147160.

Dobbin, F., \& Jung, J. (2011). Corporate board gender diversity and stock performance: The competence gap or institutional investor bias? North Carolina Law Review, 89(3), 809838.

Domhoff, G. W. (2002). Who rules America: Power and politics. New York, NY: McGraw-Hill.

Ewick, P. \& Silbey, S. S. (1998). The common place of law: Stories from everyday life. Chicago, IL: University of Chicago Press.

Fama, E., and Jensen, M. C. (1983). Separation of ownership and control. Journal of Law and Economics, 26, 301-326.

Finkelstein, S., \& Mooney, A. C. (2003). Not the usual suspects: How to use board process to make boards better. Academy of Management Executive, 17(2), 101-113.

Forbes, D. P., \& Milliken, F. J. (1999). Cognition and corporate governance: Understanding boards of directors as strategic decision-making groups. Academy of Management Review, 24(3), 489-505.

Forstenlechner, I., Lettice, F., \& Özbilgin, M. F. (2012). Questioning quotas: Applying a relational framework for diversity management practices in the United Arab Emirates. Human Resource Management Journal, 22(3), 299-315.

Fray, D., \& Guillaume, Y. (2007). Team diversity. In S. Clegg \& J. R. Bailey (Eds.), International encyclopedia of organization studies (1510-1513). Thousand Oaks, CA: Sage.

Hafsi, T., \& Turgut, G. (2012). Boardroom diversity and its effect on social performance: Conceptualization and empirical evidence. Journal of Business Ethics, 112(5), 463-479. 
Haslam, A. S., \& Ryan, M. K. (2008). The road to the glass cliff: Differences in the perceived suitability of men and women for leadership positions in succeeding and failing organizations. Leadership Quarterly, 19, 530-546.

Haslam, A. S., Ryan, M. K., Kulich, C., Trojanowski, G., \& Atkins, A. (2010). Investing with prejudice: The relationship between women's presence on company boards and objective and subjective measures of company performance. British Journal of Management, 21(4), 484-497.

Hatch, M. J. (1997). Irony and the social construction of contradiction in the humor of a management team. Organization Science, 8, 275-288.

Higgs, D. (2003). Review of the role and effectiveness of nonexecutive directors. London, England: Department of Trade and Industry.

Hillman, A. J., \& Dalziel, T. (2003). Boards of directors and firm performance: Integrating agency and resource dependence theories. Academy of Management Review, 28(3), 383396.

Hillman, A. J., Shropshire, C., \& Cannella, A. A. Jr. (2007). Organizational predictors of women of corporate boards. Academy of Management Journal, 50(4), 941-952.

Hoogendoorn, H., Oosterbeek, H., \& van Praag, M. (2011). The impact of gender diversity on the performance of business teams: Evidence from a field experiment. Tinbergen Institute Discussion Paper, 074/3.

Idris, A. (2009). Management styles and innovation in women-owned enterprises. African Journal of Business Management, 3(9), 416-425.

Jensen, M. C., \& Meckling, W. H. (1976). Theory of the firm: Managerial behavior, agency costs, and ownership structure. Journal of Financial Economics, 3(4), 305-360.

Johnson, J. L., Daily, C. M., \& Ellstrand, A. E. (1996). Boards of directors: A review and research agenda. Journal of Management, 22(3), 409-438.

Judge, E. (2003, November 11). Women on board: Help or hindrance? The Times, p. 21.

Kakabadse, A. \& Kakabadse, N. (2008). Leading the board: The six disciplines of world class chairmen. London, England: Palgrave Macmillan.

Kakabadse, A., Kakabadse, N., \& Barratt, R. (2006). Chairman and chief executive officer (CEO): That sacred and secret relationship. Journal of Management Development, 25(2), 134-150.

Kakabadse, A. P., Kakabadse, N. K., \& Knyght, R. (2010) The chemistry factor in the chairman/CEO relationship. European Management Journal, 28(4), 285-296.

Kaplan, C. D., Korf, D., \& Sterk, C. (1987). Temporal and social context of heroin-using populations: An illustration of the snowball sampling technique. Journal of Nervous Mental Disorders, 175(9), 566-574.

Karatas-Ozkan, M., \& Chell, E. (2010). Nascent entrepreneurship and learning. Cheltenham, England: Edward Elgar. 
Kramer, V. W., Konrad, A. M., \& Erkut, S. (2006). Critical mass on corporate boards: Why three or more women enhance governance. Wellesley Center for Women, Report No. WCW 11.

Kvale, S. (1996). InterViews: An introduction to qualitative research interviewing. London, England: Sage.

Lindenberg, S. (2003). The cognitive side of governance. In V. Buskens, W. Raub, \& C. Snijders (Eds.), The governance of relations in markets and organizations. Amsterdam, Netherlands/London, England: JAI Press.

Lukes, S. (2005). Power: A radical view. Basingstoke, England: Palgrave Macmillan. Machold, S., Pervaiz, A., \& Farquah, S. (2008). Corporate governance and ethics: A feminist perspective. Journal of Business Ethics, 81(6), 665-678.

Maclean, M., Harvey, C., \& Chia, R. (2010). Dominant corporate agents and the power elite in France and Britain. Organization Studies, 31(3), 327-348.

Matsa, D. A., \& Miller, A. R. (2011, June 22). A female style in corporate leadership? Evidence from quotas. Retrieved from SSRN, http://ssrn.com/abstract=1636047

McKinsey \& Company. (2010). Woman matter: Moving women to the top: McKinsey global survey results. Retrieved from http://www.mckinsey.com/locations/paris/home/womenmatter.asp

Miller, T., \& Triana, M. (2009). Demographic diversity in the boardroom: Mediators of the board diversity-firm performance relationship. Journal of Management Studies, 46(5), 755-786.

Milliken, F., \& Martins, L. (1996). Searching for common threads: Understanding the multiple effects of diversity in organizational groups. Academy of Management Review, 21(2), 402-433.

Nadler, D. A. (2004). Building better boards. Harvard Business Review, 82(5), 102-111.

News Alert. (2012). FTSE 100 set to miss the Lord Davies' target for the female composition of boards. Retrieved from SMWeb, http://www.smeweb.com/index.php?option=com_content\&view=article\&id=3389:ftse100-set-to-miss-women-on-boards-target\&catid=59:news\&Itemid=105

Özbilgin, M., \& Tatli, A. (2005). Book review essay: Understanding Bourdieu's contribution to organization and management studies. Academy of Management Review, 30(4), 855877.

Özbilgin, M. F. (2006). Relational methods in organization studies: A review of the field. In O. Kyriakidou \& M. F. Özbilgin (Eds.), Relational perspectives in organization studies: A research companion (pp. 244-264). Cheltenham, England: Edward Elgar.

Özbilgin, M. F., Beauregard, T. A., Tatli, A., \& Bell, M. P. (2011). Work-life, diversity and intersectionality: A critical review and research agenda. International Journal of Management Reviews, 13(2), 177-198.

Peteraf, M. (1993). The cornerstones of competitive advantage: A resource-based view. Strategic Management Journal, 14(3), 179-191. 
Pettigrew, A., \& McNulty, T. (1995). Power and influence in and around the boardroom. Human Relations, 48, 845-873.

Pfeffer, J. (1972). Size and composition of corporate boards of directors: The organization and its environment. Administrative Science Quarterly, 17, 218-228.

Phillips, A. (1998). The politics of presence. Oxford, England: Oxford University Press.

Pye, A., \& Pettigrew, A. (2005). Studying board context, process and dynamics: Some challenges for the future. British Journal of Management, 16,(Suppl 1), 27-38.

Rhoades, D. L., Rechner, P. L., \& Sundaramurthy, C. (2000). Board composition and financial performance: A meta-analysis of the influence of outside directors. Journal of Managerial Issues, 12(1), 76-91.

Rhodes, W., Kling, R., \& Johnston, P. (2004). A model-based approach for estimating prevalence of hard to reach populations. Retrieved from http://www.abtassoc.com/reports/Final_Methodology_surveying_htr_populations.pdf

Rindova, V. (1999). What corporate boards have to do with strategy? A cognitive perspective. Journal of Management Studies, 36, 953-975.

Roberts, J., McNulty, T., \& Stiles, P. (2005). Beyond agency conceptions of the work of the nonexecutive director: Creating accountability in the boardroom. British Journal of Management, 16, S5-S26.

Robinson, G., \& Dechant, K. (1997). Building a business case for diversity. Academy of Management Executive, 11(3), 21-31.

Rodrigo, B. P. (2005). The politics of presence and multi-ethnic Sweden: About taking your seat in democracy (Närvarons politik och det mångetniska Sverige. Om att ta plats I demokratin), Gothenburg, Sweden: School of Public Administration, Gothenburg University.

Ross-Smith, A., \& Huppatz, K. (2010). Management, women and gender capital. Gender, Work and Organization, 17(5), 547-566.

Ryan, M. K., \& Haslam, A. S. (2007). The glass cliff: Exploring the dynamics surrounding women's appointment to precarious leadership positions. Academy of Management Review, 32(2), 549-572.

Ryan, M. K., Haslam, S. A., Hersby, M. D., \& Bongiorno, R. (2011). Think crisis-think female: The glass cliff and contextual variation in the think manager-think male stereotype. Journal of Applied Psychology, 96(3), 470-484.

Sayce, S., \& Özbilgin, M. (2014). Pension trusteeship and diversity in the UK: A new boardroom recipe for change or continuity? Economic and Industrial Democracy, 35, 49-69.

Schwandt, T. A. (2000). Three epistemological stances for qualitative inquiry: Interpretivism, hermeneutics, and social constructionism. In N. K. Denzin \& Y. S. Lincoln (Eds.), Handbook of qualitative research (pp. 189-214). Thousand Oaks, CA: Sage.

Sheridan, A. J. (1995). Affirmative action in Australia-employment statistics can't tell the whole story. Women in Management Review, 10(2), 26-34. 
Shleifer, A., \& Vishny, R. W. (1997). A survey of corporate governance. Journal of Finance, 52(6), 759-783.

Singh, V. (2007). Ethnic diversity on top corporate boards: A resource dependency perspective. International Journal of Human Resource Management, 18(12), 2128-2146.

Singh, V., Terjesen, S., \& Vinnicombe, S. (2008). Newly appointed directors in the boardroom: How do women and men differ? European Management Journal, 26(1), 48-58.

Spencer Stuart. (2010). Spencer Stuart board index. Chicago, IL: Author.

Stacey, R. D. (2007). Strategic management and organisational Dynamics: The challenge of complexity (5th ed.). London, England: Prentice Hall.

Syed, J., \& Murray, P. (2008). A cultural feminist approach towards managing diversity in top management teams. Equal Opportunities International, 27(5), 413-432.

Tatli, A., \& Özbilgin, M. (2012). An emic approach to intersectional study of diversity at work. International Journal of Management Reviews, 14(2), 180-200.

Tatli, A., Vassilopoulou, J., Ariss, A., \& Özbilgin, M. (2012). The role of regulatory and temporal context in the construction of diversity discourses: The case of the UK, France and Germany. European Journal of Industrial Relations, 18(4), 293-308.

Tienari, J., Vaara, E., \& Merilainen, S. (2010). Becoming an international man: Top management masculinities in the making of a multinational corporation. Equality, Diversity and Inclusion: An International Journal, 29(1), 38-52.

Tyson, L. (2003). The Tyson report on the recruitment and development of non-executive directors. London, England: London Business School.

United Nations Development Programme (UNDP). (2012). GII: Gender inequality index. Retrieved from http://hdrstats.undp.org/en/indicators/68606.html

Westphal, J. D., \& Bednar, M. K. (2005). Pluralistic ignorance in corporate boards and firms' strategic persistence in response to low firm performance. Administrative Science Quarterly, 50(2), 262-298.

Wittenberg-Cox, A., \& Maitland, A. (2008). Why women mean business. Chichester, England: Wiley. 
Table I. Population in 2010 and Sample

\begin{tabular}{|l|l|l|l|}
\hline & $\begin{array}{l}\text { United } \\
\text { Kingdom }\end{array}$ & United States & Ghana \\
\hline Number of boards with: & FTSE 50 & Fortune 50 & Club 50 \\
\hline One female & 21 & 6 & 17 \\
\hline Two females & 13 & 20 & 7 \\
\hline Three females & 9 & 13 & 3 \\
\hline More than three women directors & 0 & 6 & 0 \\
\hline Sample & 10 & 10 & 10 \\
\hline
\end{tabular}

Table II. Work Relationships in the Boardrooms

\begin{tabular}{|l|l|l|}
\hline Category & Property & Dimension \\
\hline \multirow{4}{*}{$\begin{array}{l}\text { Work Relationships in the } \\
\text { Boardrooms }\end{array}$} & Credibility & High ... Low \\
\cline { 2 - 3 } & Fitting in & Well ... Not well \\
\cline { 2 - 3 } & Emotional intelligence & High ... Low \\
\cline { 2 - 3 } & Interpersonal skills & Effective ... Ineffective \\
\cline { 2 - 3 } & Voice tone & Deep ... Shrilling \\
\cline { 2 - 3 } & Chairman's skills & High ... Low \\
\hline
\end{tabular}

Source: Compiled from data.

Table III. Women Contribution and Board Performance

\begin{tabular}{|l|l|l|}
\hline Category & Property & Dimension \\
\hline \multirow{4}{*}{ Women Contribution and } & Dialogue & Effective ... Ineffective \\
\cline { 2 - 3 } & Courage & High ... Low \\
\cline { 2 - 3 } & Innovation & High ... Low \\
\cline { 2 - 3 } & Competitive advantage & High ... Low \\
\cline { 2 - 3 } & Leadership & Effective ... Ineffective \\
\cline { 2 - 3 } & Chairperson effectiveness & Effective ... Ineffective \\
\hline
\end{tabular}

Source: Compiled from data.

Table IV. Boardroom Quotas

\begin{tabular}{|l|l|l|}
\hline Category & Property & Dimension \\
\hline Boardroom Quotas & Merit & High ... Low \\
\cline { 2 - 3 } & Wider pool & Open ... Closed \\
\cline { 2 - 3 } & Competence-based selection & High ... Low \\
\hline
\end{tabular}

Source: Compiled from data. 